\title{
Analisa Kesesuaian Antara Preskripsi Diet Dengan Kebutuhan Gizi Secara Individu Pada Pasien Diabetes Mellitus Di Rumah Sakit X
}

\section{Conformity Analysis between the Diet Prescription and Nutrients Adequacy of Diabetes Mellitus Patients at X Hospital}

\author{
Anisa Handayani*, Laksmi Karunia Tanuwijaya, Eva Putri Arfiani
}

\begin{abstract}
ABSTRAK
Latar Belakang: Penatalaksanaan gizi medis pada pasien DM harus dilakukan secara individual karena harus mempertimbangkan kebiasaan makan, metabolisme, aktivitas fisik dan adanya komorbid. Perhitungan kebutuhan pasien secara individu dapat menggunakan rumus PERKENI (Perkumpulan Endokrinologi Indonesia) dengan memperhitungkan energi basal kemudian ditambahkan atau dikurangi dengan beberapa faktor yaitu umur, berat badan, aktivitas fisik, jenis kelamin, stress metabolik.

Tujuan: Penelitian ini dilakukan untuk menganalisis kesesuaian antara preskripsi diet dengan kebutuhan gizi secara individu pada pasien DM.

Metode: Penelitian ini menggunakan metode observasi terkait data asesmen pasien yang meliputi data berat badan (BB), tinggi badan (TB), data biokimia (kadar leukosit), dan data fisik klinis, dan preskripsi diet. Data tersebut didapatkan berdasarkan informasi dari ahli gizi di RS X. Jumlah sampel pada penelitian ini sebanyak 27 pasien DM di RS X.

Hasil: Hasil penelitian menunjukkan bahwa terdapat ketidaksesuaian preskripsi diet dengan kebutuhan gizi secara individu pada pasien DM di RS X. Kategori kebutuhan energi secara individu terbagi menjadi 8 kategori, yaitu 1100 kkal, 1200 kkal, $1300 \mathrm{kkal}, 1400 \mathrm{kkal}, 1500 \mathrm{kkal}, 1600 \mathrm{kkal}, 1700 \mathrm{kkal}, 1800 \mathrm{kkal}$. Preskripsi diet pasien DM adalah $1700 \mathrm{kkal}$.

Kesimpulan: Perbandingan preskripsi diet dengan kebutuhan gizi secara individu adalah sebanyak 13 orang (48\%) berada pada kategori cukup atau sesuai, dan sebanyak 14 orang (52\%) berada pada kategori lebih atau tidak sesuai. Hal ini dikarenakan oleh beberapa faktor seperti penggunaan rumus dalam menghitung kebutuhan gizi pasien DM dan terbatasnya jenis standar diet yang disediakan rumah sakit untuk dituliskan menjadi preskripsi diet pasien DM.
\end{abstract}

Kata kunci: Diabetes Mellitus (DM), kebutuhan gizi secara individu, preskripsi diet

\section{ABSTRACT}

Background: Medical nutrition management in DM patients must be done individually because it must consider eating habits, metabolism, physical activity and comorbidities. Calculation of nutritients adequacy can use the PERKENI formula by calculating basal energy then added or reduced by several factors, namely age, weight, physical activity, gender, metabolic stress.

Objective: The aim of the study was to analysis the conformity of diet prescription and nutrients adequacy of DM patients. Method: This study used observational methods related to assessment data such as weight, hight, biochemical, and physicclinic data and diet prescription. The number of samples in this study were 27 DM patients at $X$ Hospital.

Results: Results showed that there was discrepancies of diet prescription and nutrients adequacy of DM patients. Category of nutrient adequacy devided by 8 category, $1100 \mathrm{kkal}, 1200 \mathrm{kkal}, 1300 \mathrm{kkal}, 1400 \mathrm{kkal}, 1500 \mathrm{kkal}, 1600 \mathrm{kkal}, 1700 \mathrm{kkal}$, $1800 \mathrm{kkal}$. Diet prescription of DM patients was $1700 \mathrm{kkal}$.

Conclusion: Comparison between diet prescription and nutrients adequacy $48 \%$ were mostly fall in appropriate category, and $52 \%$ were in inappropriate category. This was due to several factors such as the use of formulas in calculating nutrition adequacy of DM patients and the limited type of diet mannuals provided by hospitals to be prescribed for DM patients' diets.

Keywords: Diabetes Mellitus (DM), nutrients adequacy, diet prescription

*Korespondensi:

Anisa Handayani

Email: anisa.handayani55@gmail.com

Fakultas Kedokteran Universitas Brawijaya 


\section{PENDAHULUAN}

Diabetes Mellitus (DM) merupakan penyakit metabolik yang terjadi karena gangguan sekresi insulin, kerja insulin, atau kedua-duanya dengan karakteristik hiperglikemia ${ }^{1}$. Diagnosa DM dapat ditegakkan apabila ditemukan gejala khas DM seperti polyuria, polydipsia, polyphagia, penurunan berat badan, dan Gula Darah Sewaktu $(G D S) \geq 200 \mathrm{mg} / \mathrm{dl}^{1}$. Menurut World Health Organization (2016) pada tahun 2014, 8,5\% orang dewasa berusia 18 tahun keatas menderita DM. Pada 2015, DM adalah penyebab secara langsung 1,6 juta kematian dan pada tahun 2012 glukosa darah tinggi adalah 2,2 juta penyebab kematian lainnya ${ }^{2}$.

Beberapa penelitian menyebutkan ada hubungan antara faktor terapi diet dengan pengendalian penyakit $\mathrm{DM}^{3}$. Tujuan dari penatalaksanaan gizi medis pada DM adalah untuk mencapai dan mempertahankan kadar glukosa darah, profil lipid, dan tekanan darah dalam batas normal dan mencegah terjadinya komplikasi kronis ${ }^{4}$.

Salah satu penatalaksanaan gizi medis adalah pemberian diet melalui preskripsi diet yang dibuat oleh dokter yang kemudian akan diterjemahkan oleh ahli gizi ke dalam menu makanan ${ }^{5}$. Ketika dokter mempreskripsikan diet yang tidak tepat, maka dapat terjadi ketimpangan ${ }^{6}$. Berdasarkan penelitian yang dilakukan di RSUD. Dr. M. Ashari Pemalang, ditemukan bahwa diet yang ditentukan oleh dokter untuk penderita DM dengan energi sebesar $1700 \mathrm{kkal}$ sebanyak 93,3\% dan energi sebesar 1500 kkal sebanyak 6,7 \%. Dokter menjelaskan bahwa penderita DM yang dirawat inap membutuhkan energi 1700 kkal. Dokter dalam menentukan kebutuhan gizi pasien berdasarkan estimasi, tidak secara individual. Sebanyak 73,33\% preskripsi diet yang dibuat oleh dokter tidak sesuai dengan kebutuhan gizi pasien ${ }^{3}$.

Berdasarkan hasil wawancara dengan Ahli Gizi di RS X, pasien yang bukan MRS akan ditentukan preskripsi dietnya oleh ahli gizi sedangkan pasien yang MRS akan ditentukan preskripsi dietnya oleh perawat yang bertugas. Penentuan diet pada pasien MRS seharusnya ditentukan oleh Ahli Gizi yang bertugas. Pada proses penentuan preskripsi diet dilakukan perhitungan kebutuhan gizi pasien secara individu apabila pasien beresiko malnutrisi namun penentuan preskripsi diet tidak mempertimbangkan perhitungan kebutuhan gizi pasien secara individu tetapi dilihat dari jenis penyakit yang diderita pasien. Perhitungan kebutuhan gizi secara individu akan didekatkan/dibulatkan dengan standar diet yang disediakan rumah sakit. Pasien DM di RS X akan diberikan diet 1700 kkal namun apabila pasien mengalami komplikasi pada saluran cerna seperti DM gastropati, adanya melena dan hematemesis akan diberikan diet 1500 kkal.

Asupan energi yang berlebihan pada DM akan meningkatkan resistensi insulin 7 . The American Diabetes Association (2009), menyatakan bahwa penderita DM harus mendapatkan penatalaksanaan gizi medis secara individual karena harus mempertimbangkan kebiasaan makan, metabolisme, aktivitas fisik dan adanya komorbid ${ }^{5}$. Perhitungan kebutuhan pasien secara individu dapat menggunakan rumus PERKENI dengan memperhitungkan energi basal kemudian ditambahkan atau dikurangi dengan beberapa faktor yaitu umur, berat badan, aktivitas fisik, jenis kelamin, stress metabolik ${ }^{8}$.

Proses asuhan gizi pada pasien DM yang berlaku di RS X memungkinkan terjadinya ketimpangan selama proses tersebut terlaksana. Salah satu ketimpangan yang mungkin terjadi adalah ketidaksesuaian antara preskripsi diet dengan kebutuhan gizi secara individu pada pasien DM. Berdasarkan uraian diatas, kesesuaian pemberian diet pada pasien DM sangatlah penting, sehingga peneliti merasa perlu dilakukan penelitian terkait analisis kesesuaian antara preskripsi diet dengan kebutuhan gizi secara individu pada pasien DM di RS X.

\section{METODE}

Jenis penelitian yang digunakan adalah Cross Sectional dengan pendekatan deskriptif yaitu data dilakukan sekaligus pada saat tertentu. Data untuk variabel bebas dan variabel terkait diambil dalam waktu yang bersamaan. Tujuan dari penelitian ini adalah ingin mendapatkan gambaran tentang kesesuaian antara preskripsi diet dengan kebutuhan gizi secara individu pada pasien DM di RS X. Populasi dalam penelitian ini adalah seluruh pasien rawat inap dengan diagnosa medis DM murni maupun dengan komplikasi di RS $X$ yang berjumlah 29 pasien. Sampel yang digunakan dalam penelitian ini adalah sebagian pasien rawat inap dengan diagnosa medis DM murni maupun dengan komplikasi di Rumah Sakit $X$ yang harus memenuhi kriteria inklusi. Variabel independen dalam penelitian ini adalah kebutuhan gizi pasien DM secara individu di RS $X$. Variabel dependen dalam penelitian ini adalah preskripsi diet pada pasien DM di RS X. Penelitian ini dilaksanakan pada bulan Oktober - November 2018 di RS X. Kebutuhan gizi pasien DM pada preskripsi diet adalah perencanaan makan pasien dengan tujuan untuk penyembuhan penyakit meliputi jenis diet, kandungan zat gizi, dan kosistensi makanan yang akan diberikan kepada pasien yang dibuat berdasarkan kondisi pasien dan ditetapkan oleh ahli gizi. Diobservasi dengan menggunakan instrument berupa form preskripsi diet dan lembar observasi. Kebutuhan gizi pasien DM secara individu adalah Jumlah zat gizi minimal yang diperlukan individu dan diperhitungkan dengan mempertimbangkan beberapa faktor yaitu umur, berat badan, aktivitas fisik, jenis kelamin, stress metabolic. Diobservasi dengan menggunakan instrument perhitungan kebutuhan pasien secara individu dengan rumus PERKENI. Kesesuaian antara preskripsi diet dengan kebutuhan gizi secara individu adalah Jumlah zat gizi (energi, protein, lemak, karbohidrat) yang diberikan untuk pasien sesuai dengan kebutuhan gizi pasien secara individu yang telah dihitung menggunakan rumus PERKENI. Dikategorikan dengan menggunakan kriteria yaitu jika persentase kurang dari 90\% maka dikategorikan kurang (K), jika persentase berada pada range $90 \%-110 \%$ maka dikategorikan cukup (C)/sesuai, dan jika persentase lebih dari $110 \%$ maka dikategorikan lebih (L) ${ }^{9}$.

Sebelum melakukan pengambilan data, peneliti melakukan sidang etik terlebih dahulu di FKUB kemudian mendapatkan izin penelitian di RS X. Pengumpulan data diawali dengan melakukan tahap persiapan yaitu 
mempersiapkan administrasi perizinan pelaksanaan penelitian di RS $X$ dan mempersiapkan kelengkapan perlengkapan administrasi dan peralatan untuk keperluan penelitian serta kesiapan peneliti dalam melakukan pengambilan data. Tahap pengambilan data primer yaitu mendata pasien DM yang dirawat inap kemudian mencatat TB dan BB pasien berdasarkan informasi dari ahli gizi pada lembar observasi, kemudian menghitung dan mencatat kebutuhan gizi pasien secara individu dengan rumus PERKENI, kemudian peneliti melakukan observasi dan mencatat terkait diet yang diberikan rumah sakit pada form preskripsi diet. Tahap pengambilan data sekunder adalah melakukan wawancara dengan ahli gzi terkait alasan tidak memberikan kebutuhan gizi secara individu kepada pasien. Penelitian ini menggunakan teknik analisis deskriptif dengan persentase. Software yang digunakan dalam analisis data pada penelitian ini adalah SPSS dan Excel 2013. Data yang dianalisis untuk mengetahui kesesuaian antara preskripsi diet dengan kebutuhan gizi secara individu pada pasien DM di RS X.

\section{HASIL DAN PEMBAHASAN}

Tabel 1 menunjukkan bahwa sebagian besar responden berjenis kelamin wanita (63\%), berusia 46 55 tahun (52\%), jenis diet yang diberikan yaitu diet DM (44\%), dan semua responden memiliki faktor aktivitas yang sama yaitu mobilisasi di tempat tidur (100\%). Status gizi responden dihitung dengan menggunakan IMT yaitu berat badan $(\mathrm{kg})$ dibandingkan dengan tinggi badan $(\mathrm{m})$ kuadrat. Sebanyak 33\% responden memiliki status gizi normal dan $30 \%$ responden memiliki status gizi obesitas tingkat 1 . Faktor stress responden dilihat dari data rekam medis pasien, sebanyak $67 \%$ responden mengalami infeksi yaitu kadar leukosit responden > $10.000 \mathrm{~mm} 3$.

Tabel 1. Karakteristik Responden ( $\mathrm{N}=27)$

\begin{tabular}{|c|c|c|}
\hline & Variabel & $\mathrm{n}(\%)$ \\
\hline \multirow[t]{2}{*}{ Jenis Kelamin } & Perempuan & $17(63 \%)$ \\
\hline & Laki-laki & $10(37 \%)$ \\
\hline \multirow[t]{2}{*}{ Kelas Perawatan } & Kelas 2 & $13(48 \%)$ \\
\hline & Kelas 3 & $14(52 \%)$ \\
\hline \multirow[t]{5}{*}{ Usia } & $26-35$ tahun & $2(7 \%)$ \\
\hline & $36-45$ tahun & $2(7 \%)$ \\
\hline & $46-55$ tahun & $14(52 \%)$ \\
\hline & $56-65$ tahun & $6(22 \%)$ \\
\hline & $>65$ tahun & $3(11 \%)$ \\
\hline \multirow[t]{10}{*}{ Jenis Diet } & Diet DM & $12(44 \%)$ \\
\hline & Diet DM RP & $1(4 \%)$ \\
\hline & Diet DM RG & $1(4 \%)$ \\
\hline & Diet DM DJ & $3(11 \%)$ \\
\hline & Diet DM DJ RS & $1(4 \%)$ \\
\hline & Diet DM DJ RG & $1(4 \%)$ \\
\hline & Diet DM RG RL & $3(11 \%)$ \\
\hline & Diet DM RG RP & $1(4 \%)$ \\
\hline & Diet DM RG RS & $2(7 \%)$ \\
\hline & Diet DM RL RP & $2(7 \%)$ \\
\hline Aktivitas Fisik & Mobilisasi di tempat tidur & $27(100 \%)$ \\
\hline \multirow[t]{5}{*}{ Status Gizi } & Underweight & $4(15 \%)$ \\
\hline & Normal & $9(33 \%)$ \\
\hline & Overweight & $4(15 \%)$ \\
\hline & Obesitas tingkat 1 & $8(30 \%)$ \\
\hline & Obesitas tingkat 2 & $2(7 \%)$ \\
\hline \multirow[t]{4}{*}{ Faktor Stres } & DM Murni & $7(26 \%)$ \\
\hline & CHF, bedah minor, CVA & $7(26 \%)$ \\
\hline & Infeksi & $18(67 \%)$ \\
\hline & Post operasi elektif & $6(22 \%)$ \\
\hline
\end{tabular}

Berdasarkan tabel 2 menunjukkan kebutuhan gizi pasien DM berbeda antara satu dengan yang lainnya. Rata-rata kebutuhan energi pasien DM secara individu adalah $1551,5 \mathrm{kkal}$, rata-rata kebutuhan protein adalah 57,5 gram, rata-rata kebutuhan lemak adalah 43,1 gram, dan rata-rata kebutuhan karbohidrat adalah 233,4 gram. Kebutuhan energi setiap individu kemudian didekatkan/dibulatkan menjadi beberapa kategori standar diet untuk dilihat kategori kebutuhan energi yang memiliki frekuensi terbanyak. Kategori kebutuhan energi disajikan dalam tabel 3. Berdasarkan tabel 3 menunjukkan bahwa kebutuhan energi pasien DM secara individu terkategori menjadi 8 kategori dengan frekuensi terbanyak pada kategori energi 1500 kkal yaitu sebanyak $6(22,2 \%)$ responden dan kategori $1600 \mathrm{kkal}$ yaitu sebanyak $5(18,5 \%)$ responden. Pada kategori energi $1300 \mathrm{kkal}, 1400 \mathrm{kkal}$, dan $1800 \mathrm{kkal}$ sebanyak 4 $(14,8 \%)$ responden. Sebanyak $2(7,4 \%)$ responden 
berada pada kategori energi $1700 \mathrm{kkal}$ dan pada kategori energi $1100 \mathrm{kkal}$ dan $1200 \mathrm{kkal}$ sebanyak 1 (3,7\%) responden.

Berdasarkan tabel 4 menunjukkan bahwa preskripsi diet di RS $X$ hanya terdiri dari dua jenis yang dibedakan berdasarkan jenis diet yang diberikan. Diet lambung diberikan untuk pasien yang mengalami gangguan pencernaan seperti DM gastropati, adanya melena, dan hematemesis sedangkan diet khusus diberikan untuk semua jenis diet kecuali diet TKTP. Pada penelitian ini, semua pasien DM diberikan diet khusus 1700 dikarenakan pasien tidak mengalami gangguan pencernaan yang parah dan instalasi gizi memprioritaskan keinginan makan pasien.

Tabel 2. Kebutuhan Gizi Pasien DM Secara Individu ( $N=27$ )

\begin{tabular}{|c|c|c|c|c|c|c|}
\hline \multirow{2}{*}{$\begin{array}{l}\text { Kode } \\
\text { Resp- } \\
\text { onden }\end{array}$} & \multirow[b]{2}{*}{ Diagnosa Medis } & \multirow[b]{2}{*}{ Jenis Diet } & \multicolumn{4}{|c|}{ Kebutuhan Gizi Individu } \\
\hline & & & $\begin{array}{l}\text { Energi } \\
\text { (kkal) }\end{array}$ & $\begin{array}{l}\text { Protein } \\
\text { (gram) }\end{array}$ & $\begin{array}{l}\text { Lemak } \\
\text { (gram) }\end{array}$ & $\begin{array}{c}\text { Karbohidrat } \\
\text { (gram) }\end{array}$ \\
\hline 1 & Abd. Pain, DM, Hiper & DM & 1631,3 & 61,2 & 45,3 & 244,7 \\
\hline 2 & DM Gastropati & DM RL RP & 1322,5 & 49,6 & 36,7 & 198,4 \\
\hline 3 & NSTEACS, HF, DM & DM DJ & 1485,0 & 55,7 & 41,3 & 222,8 \\
\hline 4 & $\mathrm{CHF}+\mathrm{AF}+\mathrm{DM}$ & DM DJ & 1575,0 & 59,1 & 43,8 & 236,3 \\
\hline 5 & DM type II, foot & DM RL RP & 1740,0 & 65,3 & 48,3 & 261,0 \\
\hline 6 & DM & DM & 1525,0 & 57,2 & 42,4 & 228,8 \\
\hline 7 & Abd. Pain, DM & DM RG RS & 1625,0 & 60,9 & 45,1 & 243,8 \\
\hline 8 & Hemiparese, DM & DM RG RP & 1875,0 & 70,3 & 52,1 & 281,3 \\
\hline 9 & DM & DM & 1260,0 & 47,3 & 35,0 & 189,0 \\
\hline 10 & Vertigo, HT, DM & DM RG & 1620,0 & 60,8 & 45,0 & 243,0 \\
\hline 11 & DM & DM & 1820,0 & 68,3 & 50,6 & 273,0 \\
\hline 12 & DM, GEA & DM DJ RS & 1550,0 & 58,1 & 43,1 & 232,5 \\
\hline 13 & Selulitis, DM & DM & 1500,0 & 56,3 & 41,7 & 225,0 \\
\hline 14 & Post amputasi, DM & DM & 1178,8 & 44,2 & 32,7 & 176,8 \\
\hline 15 & DM, Hiper & DM & 1448,8 & 54,3 & 40,2 & 217,3 \\
\hline 16 & Post Skin Grafti, DM & DM & 1440,0 & 54,0 & 40,0 & 216,0 \\
\hline 17 & $\begin{array}{l}\text { DM gangrene, CKD, } \\
\text { Hipoalbumin }\end{array}$ & DM RP & 1350,0 & 32,0 & 37,5 & 221,1 \\
\hline 18 & Diabetic foot & DM & 1770,0 & 66,4 & 49,2 & 265,5 \\
\hline 19 & GEA, krisis hiperglikemia & DM RG RS & 1325,0 & 49,7 & 36,8 & 198,8 \\
\hline 20 & OF, Post PCl, DM & DM RG DJ & 1495,0 & 56,1 & 41,5 & 224,3 \\
\hline 21 & UAP, DM, Hiperglikemia & DM DJ & 1812,5 & 68,0 & 50,3 & 271,9 \\
\hline 22 & DM, vomit & DM & 1837,5 & 68,9 & 51,0 & 275,6 \\
\hline 23 & DM, CVA & DM RG RL & 1507,5 & 56,5 & 41,9 & 226,1 \\
\hline 24 & CVA, DM & DM RG RL & 1687,5 & 63,3 & 46,9 & 253,1 \\
\hline 25 & CAD, HHD, DM & DM & 1360,0 & 51,0 & 37,8 & 204,0 \\
\hline 26 & Selulitis, DM & DM & 1500,0 & 56,3 & 41,7 & 225,0 \\
\hline 27 & DM, CVA & DM RG RL & 1650,0 & 61,9 & 45,8 & 247,5 \\
\hline \multirow{2}{*}{\multicolumn{3}{|c|}{ Rata-rata \pm SD }} & 1551,5 & 57,5 & 43,1 & 233,4 \\
\hline & & & $\pm 185,9$ & $\pm 8,5$ & $\pm 5,2$ & $\pm 27,3$ \\
\hline
\end{tabular}

Keterangan: Abd. Pain $=$ Abdominal Pain $; \mathrm{DM}=$ Diabetes Mellitus $;$ Hiper $=$ Hiperglikemia $;$ NSTEACS $=$ Non-ST-segment Elevation Acute Coronary Syndromes $; \mathrm{HF}=$ Heart Failure $; \mathrm{CHF}=$ Congestive Heart Failure $; \mathrm{AF}=$ Atrial Fibrilasi $; \mathrm{HT}=$ Hipertensi ; GEA = Gastroenteritis $; \mathrm{CKD}=$ Chronic Kidney Disease $;$ Post $\mathrm{PCl}=$ Post Percutaneus Coronary Intervention ; UAP $=$ Unstable Angina Pectoris; CVA = Cerebrovascular Accident $\mathrm{CAD}=$ Coronary Artery Disease $; \mathrm{HHD}=$ Hypertensive Heart Disease

Gambar 1 hingga gambar 4 menunjukkan perbandingan kebutuhan energi dan zat gizi makro (protein, lemak, dan karbohidrat) pada pasien DM dengan preskripsi diet yang diberikan rumah sakit X. Dari 27 responden sebanyak 14 responden (52\%) mendapat preskripsi diet yang melebhi kebutuhan energi dan zat gizi makronya (protein, lemak, dan karbohidrat).

Berdasarkan tabel 5 menunjukkan bahwa sebanyak 13 pasien DM diberikan diet yang sesuai dengan kebutuhan gizi secara individu dan sebanyak 14 pasien DM diberikan diet yang tidak sesuai dengan kebutuhan gizi secara individu. Hal ini dapat dikategorikan melalui status kecukupan zat gizi yaitu energi, protein, lemak, dan karbohidrat. Apabila status kecukupan kebutuhan gizi adalah cukup maka dapat dikategorikan sesuai. Namun, apabila status kecukupan kebutuhan gizi adalah lebih atau kurang maka dapat dikategorikan tidak sesuai.

Tabel 3. Kategori Kebutuhan Energi Secara Individu

\begin{tabular}{ccc}
\hline Kategori Kebutuhan Energi (kkal) & $\mathbf{n}$ & $\mathbf{\%}$ \\
\hline 1100 & 1 & 3,7 \\
1200 & 1 & 3,7 \\
1300 & 4 & 14,8 \\
1400 & 4 & 14,8 \\
1500 & 6 & 22,2 \\
1600 & 5 & 18,5 \\
1700 & 2 & 7,4 \\
1800 & 4 & 14,8 \\
\hline
\end{tabular}


Sebanyak 13 orang (48\%) kebutuhan gizinya (energi, protein, lemak, karbohidrat) berada pada kategori cukup atau sesuai, dan sebanyak 14 orang (52\%) kebutuhan gizi pasien DM berada pada kategori lebih atau tidak sesuai.

Tabel 4. Preskripsi Diet Pasien DM di RS X

\begin{tabular}{ccccc}
\hline \multicolumn{5}{c}{ Preskripsi Diet } \\
\hline Jenis Diet & Energi (kkal) & Protein (gram) & Lemak (gram) & Karbohidrat (gram) \\
\hline Diet Lambung & 1500,0 & 56,3 & 41,7 & 225,0 \\
Diet Khusus & 1700,0 & 63,8 & 47,2 & 255,0 \\
\hline
\end{tabular}

Berdasarkan hasil penelitian, perbandingan kebutuhan gizi pasien DM dengan preskripsi diet yang diberikan oleh rumah sakit adalah tidak sesuai. Sebanyak 14 orang (52\%) kebutuhan gizi pasien DM berada pada kategori tidak sesuai atau berlebih. Rata-rata kebutuhan gizi pasien secara individu adalah 1551,5 kkal, sedangkan preskripsi diet yang diberikan rumah sakit adalah 1700 kkal. Hal ini disebabkan oleh beberapa faktor seperti penggunaan rumus dalam menghitung kebutuhan gizi pasien DM, kevalidan pengukuran antropometri untuk menghitung kebutuhan gizi pasien DM, dan terbatasnya jenis standar diet yang disediakan rumah sakit untuk dituliskan menjadi preskripsi diet pasien DM.

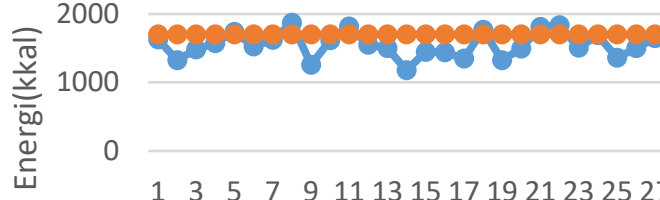

$$
\begin{aligned}
& \text { Responden } \\
& \text { - Kebutuhan Gizi (Energi) Individu } \\
& \text {-Preskripsi Diet }
\end{aligned}
$$

Gambar 1. Perbandingan Kebutuhan Energi Pasien DM dengan Preskripsi Diet yang Diberikan Rumah Sakit X.

Penelitian ini menghitung kebutuhan gizi pasien DM sebanyak 27 responden dengan kondisi kesehatan yang berbeda-beda. Kebutuhan gizi pasien DM memperhitungkan energi basal yang ditambahi atau dikurangi dengan beberapa faktor. Energi basal adalah berat badan pasien yang dikalikan dengan 25-30 kkal berdasarkan jenis kelamin pasien. Total kebutuhan energi adalah energi basal ditambahi dengan persentase faktor stress, faktor aktivitas, status gizi, dan dikurangi dengan koreksi umur ${ }^{8}$. Jika dibandingkan dengan perhitungan kebutuhan gizi menggunakan tabel Gupta (2010), perhitungan ini lebih mudah digunakan untuk menghitung kebutuhan gizi pasien DM secara individu namun kekurangannya adalah tabel Gupta tidak mempertimbangkan faktor stress, faktor aktivitas, dan koreksi umur yang mempengaruhi metabolisme pasien DM. Tabel Gupta hanya mempertimbangkan status gizi dan jenis kelamin pasien $\mathrm{DM}^{10}$. Peneliti tidak menggunakan rumus Harris Benedict dikarenakan rumus tersebut tidak spesifik untuk perhitungan kebutuhan gizi pasien DM dan menimbulkan overestimated dalam perhitungan kebutuhan gizi. Hal ini didukung oleh

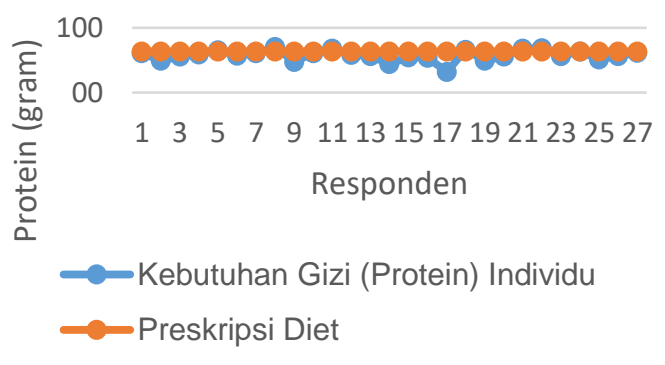

Gambar 2. Perbandingan Kebutuhan Protein Pasien DM dengan Preskripsi Diet yang Diberikan Rumah Sakit X.

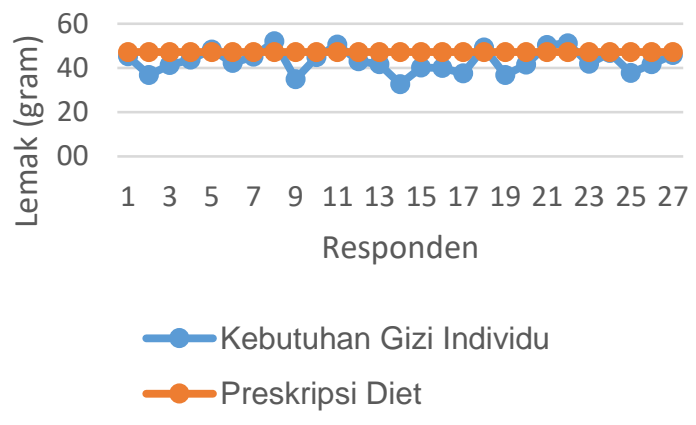

Gambar 3. Perbandingan Kebutuhan Lemak Pasien DM dengan Preskripsi Diet yang Diberikan Rumah Sakit X.

pernyataan Douglas et al (2008) yang menemukan bahwa keakuratan rumus Harris Benedict lebih rendah pada wanita yang mengalami kelebihan berat badan dan wanita dengan etnis AA.

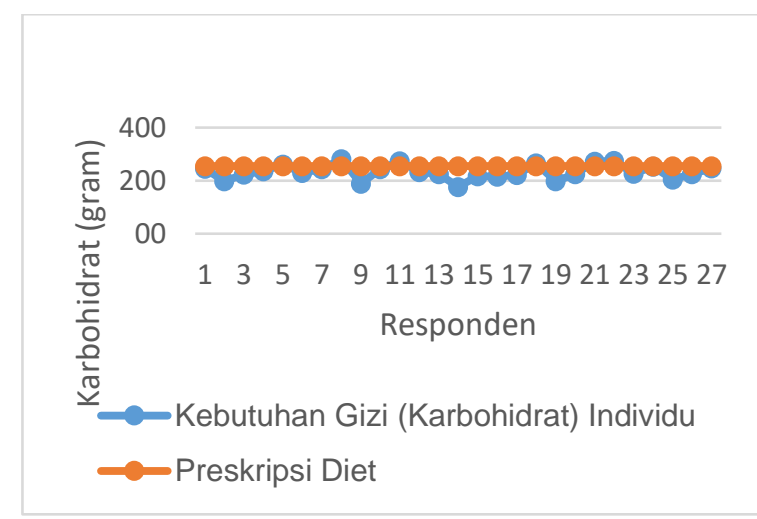

Gambar 4. Pebandingan Kebutuhan Karbohidrat Pasien DM dengan Preskripsi Diet yang Diberikan Rumah Sakit $\mathrm{X}$. 
Rumus Harris Benedict secara signifikan memperhitungkan TEE dengan overestimated ${ }^{11}$. Perhitungan kebutuhan gizi secara individu yang dilakukan oleh ahli gizi RS X menggunakan rumus Harris Benedict, sehingga perhitungan energi dan zat gizi pasien tersebut mengalami overestimated karena perhitungan Harris Benedict tidak spesifik untuk pasien DM. Setelah dilakukan perhitungan kebutuhan zat gizi, kemudian perhitungan tersebut didekatkan/dibulatkan dengan standar diet untuk pasien DM yang tersedia di rumah sakit untuk dijadikan preskripsi diet. Standar diet untuk makanan biasa hanya tersedia satu jenis, yaitu diet $1700 \mathrm{kkal}$, sedangkan standar diet untuk makanan bubur halus hanya tersedia satu jenis juga, yaitu diet 1500 kkal. Hal ini menyebabkan sebanyak 14 orang (52\%) berada pada kategori lebih atau tidak sesuai, karena perhitungan kebutuhan gizi tersebut secara tidak langsung menjadi percuma karena hanya akan didekatkan/dibulatkan dengan standar diet $1700 \mathrm{kkal}$. Sehingga preskripsi diet yang diberikan akan melebihi kebutuhan gizi pasien secara individu.

Tabel 5 Kesesuaian Preskripsi Diet dengan Kebutuhan Gizi Individu

\begin{tabular}{|c|c|c|c|c|c|}
\hline \multirow{2}{*}{ Kode Responden } & \multicolumn{4}{|c|}{ Status Kecukupan Zat Gizi } & \multirow{2}{*}{ Kesesuaian } \\
\hline & Energi & Protein & Lemak & Karbohidrat & \\
\hline 1 & C & $\mathrm{C}$ & C & $\mathrm{C}$ & $S$ \\
\hline 2 & L & $\mathrm{L}$ & $\mathrm{L}$ & $\mathrm{L}$ & TS \\
\hline 3 & L & $\mathrm{L}$ & L & $\mathrm{L}$ & TS \\
\hline 4 & C & $\mathrm{C}$ & C & C & $\mathrm{S}$ \\
\hline 5 & C & $\mathrm{C}$ & C & C & $S$ \\
\hline 6 & L & $\mathrm{L}$ & L & $\mathrm{L}$ & TS \\
\hline 7 & $\mathrm{C}$ & $\mathrm{C}$ & C & $\mathrm{C}$ & $\mathrm{s}$ \\
\hline 8 & C & $\mathrm{C}$ & C & C & $S$ \\
\hline 9 & $\mathrm{~L}$ & $\mathrm{~L}$ & $\mathrm{~L}$ & $\mathrm{~L}$ & TS \\
\hline 10 & C & $\mathrm{C}$ & C & C & $\mathrm{S}$ \\
\hline 11 & C & $C$ & $C$ & $C$ & $S$ \\
\hline 12 & C & $C$ & C & C & $S$ \\
\hline 13 & $\mathrm{~L}$ & $\mathrm{~L}$ & $\mathrm{~L}$ & $\mathrm{~L}$ & TS \\
\hline 14 & L & $\mathrm{L}$ & L & L & TS \\
\hline 15 & L & $\mathrm{L}$ & $\mathrm{L}$ & $\mathrm{L}$ & TS \\
\hline 16 & L & $\mathrm{L}$ & $\mathrm{L}$ & $\mathrm{L}$ & TS \\
\hline 17 & L & $\mathrm{L}$ & $\mathrm{L}$ & $\mathrm{L}$ & TS \\
\hline 18 & $C$ & $C$ & C & C & $S$ \\
\hline 19 & L & $\mathrm{L}$ & L & $\mathrm{L}$ & TS \\
\hline 20 & $\mathrm{~L}$ & $\mathrm{~L}$ & $\mathrm{~L}$ & $\mathrm{~L}$ & TS \\
\hline 21 & C & $C$ & C & C & $S$ \\
\hline 22 & C & $C$ & C & $C$ & $S$ \\
\hline 23 & L & $\mathrm{L}$ & $\mathrm{L}$ & $\mathrm{L}$ & TS \\
\hline 24 & C & $C$ & $C$ & $C$ & $S$ \\
\hline 25 & L & $\mathrm{L}$ & L & L & TS \\
\hline 26 & L & $\mathrm{L}$ & $\mathrm{L}$ & $\mathrm{L}$ & TS \\
\hline 27 & C & $C$ & C & C & $S$ \\
\hline
\end{tabular}

Faktor lain yang menyebabkan ketidaksesuaian kebutuhan gizi secara individu dengan preskripsi diet adalah kevalidan dari pengukuran antropometri. Berdasarkan hasil observasi, peneliti belum pernah melihat adanya pengukuran antropometri yang dilakukan oleh ahli gizi secara langsung sehingga peneliti tidak mengetahui metode apa yang dilakukan oleh ahli gizi $\mathrm{RS} X$ dalam mengukur antropometri. Hal tersebut menyebabkan peneliti tidak dapat menentukan kevalidan data antropometri. Kevalidan data antropometri memiliki pengaruh besar dalam perhitungan kebutuhan gizi pasien secara individu, karena data BB dan TB digunakan dalam rumus PERKENI maupun Harris Benedict. Sehingga, perhitungan kebutuhan gizi pasien dapat menjadi overestimated atau underestimated apabila pengukuran antropometri tidak valid dan tidak akurat.

ESPEN merekomendasikan skrining gizi dilakukan pada awal pasien MRS (1×24 jam MRS). Jika pasien tidak beresiko malnutrisi, maka dianjurkan dilakukan reskrining setelah satu minggu, namun jika pasien beresiko malnutrisi maka dilanjutkan pengkajian atau assessment gizi kemudian dilakukan asuhan gizi oleh ahli gizi ${ }^{12,13}$.

Berdasarkan hasil wawancara, ahli gizi menyatakan bahwa penentuan preskripsi diet $1700 \mathrm{kkal}$ dan 1500 kkal adalah dengan mempertimbangkan kebutuhan gizi pada usia dewasa dan kemampuan daya terima pasien. Selain itu, faktor lain seperti mempermudah penyajian makanan dan survei plate waste juga ikut mempengaruhi penentuan preskripsi diet. Penentuan preskripsi diet pasien seharusnya mempertimbangkan banyak hal seperti kondisi komplikasi yang diderita pasien, usia pasien, jenis kelamin, dan aktivitas pasien. Berdasarkan hasil penelitian, rata-rata kebutuhan gizi pasien DM secara individu adalah 1551,5 kkal dengan kriteria usia responden tergolong usia dewasa dan daya terima responden terhadap makanan tergolong baik. 
Berdasarkan hasil wawancara, ahli gizi menyatakan bahwa preskripsi diet di RS $X$ hanya memiliki dua standar diet dikarenakan untuk meningkatkan efisiensi waktu saat penyajian makanan dan adanya ketidakpatuhan petugas gizi saat pemorsian makanan apabila Instalasi Gizi memiliki banyak standar diet. Ketidakpatuhan petugas gizi diketahui dari pengamatan oleh ahli gizi, contoh ketidakpatuhan yang dilakukan petugas gizi adalah tidak memorsikan nasi untuk pasien DM sesuai dengan standar. Ketidakpatuhan petugas gizi ini terjadi dikarenakan hanya terdapat 1 ahli gizi yang mengontrol petugas gizi dan ahli gizi itu pun tidak dikhususkan untuk mengontrol petugas gizi saja melainkan juga mengerjakan tugas lain.

Berdasarkan hasil wawancara dengan ahli gizi, ahli gizi menyatakan ada beberapa waktu ADIME tidak terlaksana secara lengkap yaitu pada saat akreditasi, hal ini dikarenakan ahli gizi yang bertugas tidak dapat melaksanakan tugasnya karena harus mengerjakan tugas lain. Ada beberapa ahli gizi yang merangkap menjadi komite sehingga tugas ahli gizi pada saat itu terbengkalai namun ADIME tetap dilakukan keesokan harinya, karena ADIME harus dituliskan di rekam medis setiap harinya.

Berdasarkan hasil penelitian diperoleh hasil sebanyak 13 orang (48\%) kebutuhan gizinya berada pada kategori cukup atau sesuai, dan sebanyak 14 orang (52\%) kebutuhan gizinya berada pada kategori lebih atau tidak sesuai. Hal ini dikarenakan penatalaksanaan diet DM di RS $X$ belum menggunakan rumus perhitungan kebutuhan gizi yang sesuai untuk pasien DM dan RS $X$ hanya memiliki dua jenis preskripsi diet. Ahli gizi menjelaskan bahwa hal tersebut dilakukan untuk memudahkan penyajian karena penyelenggaraan makanan dilakukan secara massal, selain itu juga untuk mengurangi plate waste, dan untuk menyesuaikan kebutuhan gizi dengan rata-rata usia pasien DM di RS X.

The American Diabetes Association (2009), menyatakan bahwa penderita DM harus mendapatkan penatalaksanaan gizi medis secara individual karena harus mempertimbangkan kebiasaan makan, metabolisme, aktivitas fisik dan adanya komorbid6. Asupan energi yang berlebihan pada DM akan meningkatkan resistensi insulin ${ }^{3,14}$.

Berdasarkan penelitian yang dilakukan Ali et al (2006) kalori yang tinggi yang diberikan pada hewan unta yang DM membuktikan bahwa kadar gula darah meningkat signifikan sebanyak $21 \%$, menurunnya kadar insulin secara signifikan, dan kadar LDH yang meningkat dibandingkan dengan kelompok kontrol ${ }^{4,7,15}$.

Berdasarkan hasil penelitian kategori kebutuhan gizi secara individu pada pasien DM yang terbanyak adalah pada kategori energi $1500 \mathrm{kkal}$ yaitu sebanyak 6 orang $(22,2 \%)$ sehingga peneliti merekomendasikan untuk membuat standar diet baru yaitu $1500 \mathrm{kkal}$ dalam bentuk makanan biasa. Sehingga pada saat pembuatan preskripsi diet, kebutuhan gizi pasien DM secara individu dapat dilakukan pendekatan ke standar diet $1500 \mathrm{kkal}$ dan $1700 \mathrm{kkal}$ dengan bentuk makanan biasa dan variasi menu beragam.

Kelemahan penelitian ini adalah peneliti hanya memiliki data sekunder yaitu data antropometri berdasarkan informasi dari ahli gizi dan hasil wawancara dengan ahli gizi hal ini dikarenakan peneliti tidak memiliki akses untuk melihat rekam medis pasien dan untuk kontak langsung dengan pasien terkait pengukuran antropometri secara langsung.

\section{KESIMPULAN}

Sebanyak 13 orang (48\%) kebutuhan gizinya (energi, protein, lemak, karbohidrat) berada pada kategori cukup atau sesuai, dan sebanyak 14 orang (52\%) kebutuhan gizi pasien DM berada pada kategori lebih atau tidak sesuai. Untuk penelitian selanjutnya, agar mendapatkan kualitas data yang lebih baik, peneliti sebaiknya melakukan pengukuran antropometri secara langsung dengan pasien dan melihat rekam medis secara langsung.

\section{ACKNOWLEDGMENT}

Penulis mengucapkan terima kasih kepada pihak Instalasi Gizi RS $X$ yang telah memberi izin penelitian dan dosen Program Studi IImu Gizi FK Universitas Brawijaya atas bimbingan dan saran yang diberikan sehingga penulisan artikel ini dapat terselesaikan.

\section{REFERENS|}

1. Ndraha, S. Diabetes Melitus Tipe 2 Dan Tatalaksana Terkini. Medicinus 27, 9-16 (2014).

2. World Health Organization. Diabetes Fakta dan Angka. Diabetes di Dunia (2016).

3. Wahyuni, E. S. Evaluasi Tatalaksana Terapi Diet Pada Penderita Diabetes Mellitus Di Ruang. (2006).

4. Tumiwa, F. A. \& Langi, Y. A. Terapi gizi medis pada diabetes melitus. J. Biomedik 2, 2010 (2010).

5. Laksmini, P. A. et al. Analisis Kesesuaian Kandungan Energi dan Protein pada Terapi Gizi Medik di RSUP Sanglah Denpasar Agreement Analysis of Energy and Protein Contents during Medical Nutrition Therapy at Sanglah Hospital Denpasar Pendahuluan Metode Metode yang digunakan adala. 4, (2016).

6. Kim, K., Kim, M. \& Lee, K.-E. Assessment of foodservice quality and identification of improvement strategies using hospital foodservice quality model. Nutr. Res. Pract. 4, 163 (2010).

7. Azrimaidaliza. Asupan Zat Gizi dan Penyakit Diabetes Mellitus. J. Kesehat. Masy. 6, 36-41 (2011).

8. PERKENI. Konsensus Pengendalian dan Pencegahan Diabetes Melitus Tipe 2 di Indonesia $2015 . \quad$ Perkeni (2015). doi:10.1017/СВ09781107415324.004

9. Hulst, J. M. et al. Adequate feeding and the usefulness of the respiratory quotient in critically ill children. 21, 192-198 (2005).

10. Gupta, Sunil. Diet in Diabetes. Medicine Update (2011).

11. Douglas, C. C. et al. Ability of the Harris Benedict formula to predict energy requirements differs 
with weight history and ethnicity. NIH Public Access. 27, 194-199 (2008).

12. Triwahyu, S. \& Alamsyah, A. Metode Skrining Gizi di Rumah Sakit dengan MST Lebih Efektif dibandingkan SGA Nutrition Screening Method in Hospital with MST is More Effective than SGA. 28, 68-71 (2013).
13. Schenker, S. Undernutrition in the UK. 87-120 (2003).

14. Kerner, W. Definition, Classification and Diagnosis of Diabetes Mellitus. 384-386 (2014).

15. Bouziana, S. D. \& Tziomalos, K. Malnutrition in Patients with Acute Stroke. 2011, (2011). 